Paula Wiśniewska

Uniwersytet Wroctawski

\title{
MECHANIZM KWOT W ŚWIETLE UREGULOWAŃ KODEKSU WYBORCZEGO Z 2011 ROKU
}

\section{Wprowadzenie}

Kobiety uzyskały w Polsce czynne i bierne prawo wyborcze w 1918 roku na mocy dekretu o ordynacji wyborczej, wydanego przez Józefa Piłsudskiego. Już w 1919 roku mogły po raz pierwszy skorzystać z biernego prawa wyborczego startując w wyborach do Sejmu Ustawodawczego. Pomimo tego, że w Polsce kobiety jako pierwsze w Europie uzyskały prawa wyborcze, to wciąż stanowią niewielką reprezentację w polskim parlamencie. W 1991 w Sejmie było 10\% kobiet, a w Senacie 8\%. W 1993 roku ich odsetek w Sejmie i w Senacie wzrósł do 13\%. W kadencji Sejmu w 1997 roku odsetek kobiet utrzymał się na poziomie 13\%, a w Senacie spadł do $12 \%$. Dopiero po wyborach parlamentarnych w 2001 roku reprezentacja kobiet wzrosła do $20 \%$ w Sejmie i $23 \%$ w Senacie. Na poziomie $20 \%$ utrzymał się odsetek kobiet w Sejmie zarówno po wyborach w 2005 i 2007 roku, natomiast w Senacie zmalał do $14 \%$ w 2005 roku i 8\% w 2007 roku. ${ }^{1}$ Niska partycypacja kobiet w parlamencie nie jest problemem tylko w Polsce, ale dotyka całą Europę. Mechanizmem stosowanym na świecie, który ma na celu ułatwienie kobietom korzystania $\mathrm{z}$ biernego prawa wyborczego, są parytety i kwoty wyborcze. Na takie rozwiązanie zdecydowano się m.in. we Francji, Belgii i Słowenii. Za sprawą Kongresu Kobiet ${ }^{2}$ w polskich mediach i środowisku politycznym w 2009 roku rozgorzała dyskusja na temat wprowadzenia parytetów do polskiej ordynacji wyborczej, czego efektem było uchwalenie tzw. ustawy kwotowej ${ }^{3}$ w 2011 roku. Zanim jednak ustawa została uchwalona, przeszła długą drogę legislacyjną oraz znacznie zmieniono jej pierwot-

1 B. Balińska, Polityka równości płci Polska 2007 Raport, Warszawa 2007, s. 25.

2 Kongres Kobiet to ruch społeczny, aktywizujący kobiety w Polsce społecznie i politycznie. Punktem wyjścia były działania podjęte wokół organizacji I Kongresu Kobiet, czyli zjazdu ponad 4. tys. kobiet z całego kraju, które dyskutowały o wkładzie kobiet w historię ostatniego 20-lecia w Polsce. województw, ustawy - Ordynacja wyborcza do Sejmu Rzeczypospolitej Polskiej i do Senatu Rzeczypospolitej Polskiej oraz ustawy - Ordynacja wyborcza do Parlamentu Europejskiego (Dz.U. z 2011 r. Nr 34, poz. 172). 
nyzapis. W ostatecznym kształcie wprowadziła kwoty wyborcze, a nie parytety, jak pierwotnie zakładał obywatelski projekt ustawy. Jak pokazały wybory w 2011 roku, przyjęte rozwiązanie nie zapewniło jednak znacznego wzrostu reprezentacji kobiet w Sejmie, czego następstwem jest kolejny projekt ustawy wprowadzającej parytety suwakowe, czyli naprzemienne umieszczenie kandydatów i kandydatek na liście wyborczej. W niniejszym opracowaniu zostanie pokazane, jak wyglądał zgłoszony obywatelski projekt ustawy parytetowej, następnie zostanie poddana analizie ustawa z 2011 roku o zmianie ordynacji wyborczej do Sejmu, Senatu, rady gmin i Parlamentu Europejskiego oraz pokazane skutki jej wprowadzenia i możliwe udoskonalenie przyjętych rozwiązań prawnych.

\section{Kwoty czy parytety - ujęcie definicyjne}

W dyskursie politycznym oraz w mediach mylnie jest używany termin „kwoty” i ,parytety”, często te dwa pojęcia są stosowane zamiennie, chociaż mają różne znaczenie. Parytety (z łac. paritas, franc. parité znaczy równość) ${ }^{4}$ występują w sytuacji, kiedy wymóg reprezentacji jednej z grupy stanowi liczbę adekwatną do udziału tej grupy w całej populacji. W przypadku parytetów wyborczych oznacza to, że 50\% miejsc na listach wyborczych powinny zajmować kobiety. Kwoty są definiowane przez Pippę Norris 5 jako ,instrument wprowadzający określone kryteria, w postaci minimalnego lub maksymalnego progu dla danej grupy, w procedurę selekcji członków do organów pochodzących z wyborów powszechnych albo z nominacji w sferze publicznej, albo też do rekrutacji w sektorze prywatnym". ${ }^{6}$ Zatem kwoty nie uściślają, jaki stosunek procentowy powinna stanowić grupa kobiet, a jaki grupa mężczyzn. System kwotowy może być wprowadzony na poziomie konstytucyjnym, ustawowym i w regulacjach wewnątrzpartyjnych. ${ }^{7}$ We Francji wprowadzenie kwot płciowych wiązało się ze zmianą konstytucji. W Polsce mamy kwoty ustawowe, ale przed 2011 rokiem pojawiły się też w regulacjach wewnątrzpartyjnych tzw. dobrowolne kwoty (SLD, UP, UW, PO). ${ }^{8}$ Możemy mieć też do czynienia z sytuacją, kiedy brak spełnienia wymogów kwot niesie za sobą konsekwencje w postaci niezarejestrowania listy (Polska, Słowenia), pozostawienia miejsca niezapełnionego, jeśli nie startuje z niego kobieta (Belgia) lub skutkuje to zmniejszeniem dofinansowania partii ze środków publicznych (Francja). ${ }^{9} \mathrm{~W}$ niektórych państwach mamy do czynienia z suwakami, czyli rodzajem kwot, który wprowadza obowiązek naprzemiennego

Pippa Norris - amerykańska politolog, która w swoich badaniach koncentruje się na wyrównywaniu szans kobiet i mężczyzn w polityce.

Ł. Wawrowski, Polityka równych szans. Instytucjonalne mechanizmy zwiększania partycypacji kobiet w strukturach politycznych na przykładzie państw Unii Europejskiej, Toruń 2007, s. 587.

M. Fuszera, Kobiety, wybory, polityka, Warszawa 2013, s. 19.

Ł. Wawrowski, Polityka..., op. cit., s. 592.

Ibidem, s. 592. 
umieszczenia kobiet i mężczyzn na listach wyborczych. W Australii i Nowej Zelandii są zgłaszane kobiece listy kandydatów, czyli listy składające się wyłącznie z kobiet. ${ }^{10} \mathrm{~W}$ przypadku jednomandatowych okręgów wyborczych w Walii i Szkocji mamy do czynienia z parowaniem okręgów, czyli w sąsiadujących okręgach wyborczych zgłasza się kandydatów parami - w jednym okręgu kandydatem jest kobieta, a w drugim mężczyzna.

\section{Próby wprowadzenia parytetów wyborczych w Polsce}

Pierwsza propozycja wprowadzania kwot w Polsce została przedstawiona w latach dziewięćdziesiątych XX wieku, w ramach ustawy o równym statusie kobiet i mężczyzn. Projekt ustawy zakładał wprowadzenie wymogu 40\% reprezentacji osób kandydujących na listach wyborczych oraz we wszystkich gremiach nominowanych i mianowanych przez władze. Projekt przepadł w komisji przed wygaśnięciem kadencji Sejmu w 1997 roku. ${ }^{11}$ Propozycja wprowadzenia systemu kwotowego została ponownie zgłoszona w polskim Sejmie przez Unię Wolności i Parlamentarną Grupę Kobiet przed wyborami parlamentarnymi w 2001 roku. Ugrupowania zaproponowały nowelizację ordynacji wyborczej poprzez wprowadzenie obligatoryjnego wymogu 30\% kobiet na listach wyborczych. Konsekwencją niewypełnienia wymogu $30 \%$ byłoby niezarejestrowanie listy. Rozwiązanie to w ostateczności nie zostało jednak przyjęte. Ponownie problem niedoreprezentowania kobiet na listach wyborczych został poruszony na Kongresie Kobiet w 2009 roku. Kongres zorganizowano pod nazwą „Kobiety dla Polski. Polska dla Kobiet”, a jednym z jego postulatów była zmiana ordynacji wyborczej poprzez wprowadzenie zapisu o parytetach na listach wyborczych. Argumentowano, że w polityce kobiety mają nierówne szanse, są niedoreprezentowane, co przekłada się na ich niewystarczający udział w składach parlamentów. W październiku 2010 roku Obywatelski Komitet inicjatywy ustawodawczej „Czas na kobiety” skierował do Sejmu projekt ustawy „o zmianie ustawy - Ordynacji wyborczej do Sejmu Rzeczypospolitej Polskiej i Senatu Rzeczypospolitej Polskiej, ustawy - Ordynacja wyborcza do rad gmin, rad powiatów i sejmików województw oraz ustawy - Ordynacja wyborcza do Parlamentu Europejskiego, w związku z wprowadzeniem parytetu płci na listy kandydatów ${ }^{12}$ ". W projekcie proponowano do ordynacji wyborczej do Sejmu i Senatu w art. 143 dopisać ustęp:

10 M. Szewczyk, Parytet płci w ujęciu prawno-porównawczym, „Studia luridica Toruniensia” t. 9/211, Toruń 2011, s. 145.

11 M. Fuszera, Kobiety..., op. cit., s. 21.

12 Obywatelski projekt ustawy - o zmianie ustawy - Ordynacja wyborcza do Sejmu Rzeczypospolitej Polskiej i Senatu Rzeczypospolitej Polskiej, ustawy - Ordynacja wyborcza do rad gmin, rad powiatów i sejmików wojewódzkich oraz ustawy - Ordynacja wyborcza do Parlamentu Europejskiego, w związku z wprowadzeniem parytetu płci na listach kandydatów, druk sejmowy nr 2713, s. 5. 
„Liczba kobiet na liście okręgowej nie może być mniejsza niż liczba mężczyzn". ${ }^{13}$

W ustawie o ordynacji wyborczej do rad gmin, rad powiatów i sejmików wojewódzkich do art. 43 chciano dodać ustęp 2a. ${ }^{14}$

„Liczba kobiet na liście nie może być mniejsza niż liczba mężczyzn. Zasady tej nie stosuje się w przypadku wyborów uzupełniających do rady w gminie liczącej do 20.000 mieszkańców".

W uzasadnieniu zgłaszanego projektu ustawy obywatelskiej odwoływano się do zasady równości zagwarantowanej w art. 31 ust. $1^{15}$ Konstytucji RP wobec prawa oraz ustanowionej w art. 33 Konstytucji RP zasady równouprawnienia kobiet i mężczyzn, w tym także prawa kobiet do równego z mężczyznami zajmowania stanowisk, pełnienia funkcji oraz uzyskiwania godności publicznych. W uzasadnieniu skonstatowano więc, że mimo iż „kobiety stanowią trwałą większość” ogółu obywateli, to ich udział w składzie pochodzących z wyborów powszechnych organów władzy publicznej jest zdecydowanie mniejszościowy. ${ }^{16}$ Wśród konstytucjonalistów i prawników pojawiły się wątpliwości, czy ustawa parytetowa jest zgodna z Konstytucją Rzeczypospolitej Polski w świetle gwarantowanej przez Konstytucję równości. Oprócz niekonstytucyjności, przeciwnicy projektu podnosili argument, że nie uściślono w nim dokładnej liczby kobiet na listach wyborczych, więc mogłyby one zajmować $50 \%$ miejsc i więcej, bez odgórnych ograniczeń. Pojawiły się również zastrzeżenia, że projekt ingeruje $\mathrm{w}$ autonomiczność partii politycznych, a art. 11 Konstytucji RP zapewnia wolność tworzenia i działania partii politycznych w celu wpływania metodami demokratycznymi na kształtowanie polityki państwa. ${ }^{17}$ Opinie wydane do projektu ustawy były sprzeczne i nie określiły jednoznacznie, czy zaproponowany projekty ustawy jest zgodny z Konstytucją. Pierwsze czytanie ustawy w Sejmie odbyło się w styczniu 2010 roku, a następnie projekt trafił do komisji i podkomisji. Platforma Obywatelska zgłosiła poprawkę, zgodnie z którą kandydatki - kobiety i kandydaci - mężczyźni mieli stanowić po $35 \%$ osób na liście osób kandydujących w wyborach do Sejmu, Parlamentu Europejskiego i wyborach samorządowych. Ostateczne rozwiązanie przyjęte przez ustawodawcę jest kompromisem pomiędzy postulatami Kongresu Kobiet a obywatelskim projektem ustawy parytetowej.

Ibidem, s. 6.

Ibidem.

Konstytucja Rzeczypospolitej Polskiej z dnia 2 kwietnia 1997 roku (Dz.U. z 1997 r. Nr 78, poz. 483 z późn. zm.). Ibidem, s. 7.

A. Szmyt, Opinie w sprawie wprowadzenia parytetu płci na listach wyborczych, „Przegląd sejmowy”, dwumiesięcznik Rok XVIII 3(98)/2010, s. 137. 


\section{Ustawa kwotowa w Polsce}

W styczniu 2011 roku prezydent podpisał ustawę zmieniającą - Ordynacja wyborcza do rad gmin, rad powiatów i sejmików województw - Ordynacja wyborcza do Sejmu Rzeczypospolitej Polskiej i do Senatu Rzeczypospolitej Polskiej oraz ustawy - Ordynacja wyborcza do Parlamentu Europejskiego. Zapisy ustawy znalazły się w Kodeksie wyborczym z sierpnia 2011 roku. ${ }^{18}$ Artykuł 211 k.w. § 3 wprowadził wymóg kwotowy na listach wyborczych do Sejmu. Liczba kandydatów - kobiet nie może być mniejsza niż 35\% liczby wszystkich kandydatów na liście. Podobne rozwiązania zostały zawarte w przepisach szczególnych dotyczących wyborów do rad gmin, art. $425 \S 3$ k.w. Na liście, o której mowa w $§ 2$ pkt. 2 k.w.:

1) liczba kandydatów - kobiet nie może być mniejsza niż 35\% liczby wszystkich kandydatów na liście;

2) liczba kandydatów - mężczyzn nie może być mniejsza niż 35\% liczby wszystkich kandydatów na liście; ${ }^{19}$

W przepisach szczególnych dotyczących wyborów do rad powiatów art. 457 $\S 2$ k.w. w przypadku zgłoszenia listy zawierającej 3 kandydatów:

1) liczba kandydatów - kobiet

2) liczba kandydatów - mężczyzn

- nie może być mniejsza niż $1 .^{20}$

Art $213 \S 1$ k.w. nakłada sankcję na komitet wyborczy za niespełnienie wymogów kwotowych na listach wyborczych. Nie mniej niż 35\% kobiet i nie mniej niż $35 \%$ mężczyzn musi znaleźć się na liście wyborczej, aby została ona zarejestrowana. Kwoty mogą być stosowane tylko przy proporcjonalnym systemie wyborczym. Nowelizacja ordynacji wyborczej wprowadziła jednomandatowe okręgi wyborcze do Senatu i do rad gmin do 20 tys. mieszkańców, dlatego też kwoty nie obowiązują na listach wyborczych do Senatu i do rad gmin do 20 tys. mieszkańców.

\section{Kwoty wyborcze w wyborach parlamentarnych w 2011 roku}

Krótko po nowelizacji ordynacji wyborczej do Sejmu i Senatu, nadarzyła się możliwość sprawdzenia skuteczności kwot w wyborach parlamentarnych w 2011 roku. Ponieważ nowelizacja Kodeksu wyborczego zakładała również wprowadzenie okręgów jednomandatowych do Senatu, wymóg reprezentacji 35\% każdej z płci na liście kandydatów do drugiej izby nie mógł być spełniony. Komitety

Dz.U. z 2011 r. Nr 34, poz. 172.

Ustawa z dnia 5 stycznia 2011 r. - Kodeks wyborczy (Dz.U. z 2011 r. Nr 21, poz. 112 z późn. zm.).

Ibidem. 
wyborcze partii politycznych zgłosiły listy wyborcze do Sejmu uwzględniając mechanizm kwot, większość partii nawet przekroczyła minimum ustawowe i na listach kobiety stanowiły w SLD - 44,4\%, PO - 43,4\%, PSL - 41,7\%, PIS - 39, 8. ${ }^{21}$ Pomimo tego liczba kobiet w Sejmie po wyborach w 2011 roku wzrosła tylko o 3.9 punktu procentowego w porównaniu do wyborów parlamentarnych z 2007 roku, gdzie kobiety stanowiły $20 \%$. Przyczyn tego niewielkiego wzrostu można dopatrywać się $\mathrm{w}$ wykorzystaniu przez partie niedoprecyzowania $\mathrm{w}$ ustawie. $\mathrm{W}$ ordynacji wyborczej nie znalazł się bowiem zapis o tym, z jakich miejsc mają startować kandydatki, a z jakich kandydaci. Nie wprowadzono kwoty suwakowej, a zatem listy wyborcze zostały skonstruowane przez partie polityczne w taki sposób, że kobiety często były umieszczane na dalszych pozycjach listy wyborczej. Na listach zgłoszonych przed komitet wyborczy PIS kobiety na trzech pierwszych miejscach stanowiły $21,1 \%,{ }^{22}$ a pierwsze miejsce zajmowało $24,8 \%{ }^{23} \mathrm{~W}$ SLD na trzech pierwszych miejscach kandydatki stanowiły $36,6 \%,{ }^{24}$ a z pierwszego miejsca startowało $15,0 \%{ }^{25}$ kobiet. W PO 40,6\% kobiet znajdowało się w pierwszej trójce na liście wyborczej, a $34,0 \%$ startowało z pierwszego miejsca. W PSL tylko $22,0 \%$ kobiet znajdowało się na trzech pierwszych miejscach, a $15 \%$ kobiet wystawiono jako jedynki. Ruch Poparcia Palikota umieścił na pierwszym miejscu $10 \%$ kobiet, a na trzech pierwszych miejscach list wyborczych było 39,8\% kobiet. Rezultatem działania partii był niewielki wzrost odsetek kandydatek, które weszły do Sejmu. Według polityki wewnętrznej partii, pierwsze trzy miejsca na liście dostają przeważnie kandydaci, którzy są rozpoznawalni przez wyborców i pełnili już funkcje w Sejmie lub Senacie. ${ }^{26}$ PO i PIS, które zdecydowały się na umieszczenie kobiet na wysokich pozycjach, tym samym wprowadziły odpowiednio 34\% i 17\% posłanek. Na listach PSL niewiele kobiet startowało $\mathrm{z}$ wysokiej pozycji na liście, co też przełożyło się na 7\% udział posłanek w klubie parlamentarnym tej partii. Praktyka komitetów wyborczych pokazała, że ważne jest nie samo umieszczenie kobiet na liście, ale to $\mathrm{z}$ jakiego miejsca one startują.

\section{Próby wprowadzenia suwaków na listy wyborcze}

Pierwszy projekt nowelizacji Kodeksu wyborczego z sierpnia 2011 roku trafił do marszałek Sejmu Ewy Kopacz w październiku 2012 roku. Nowelizacja zaproponowana przez Ruch Palikota zakładała wprowadzenie parytetów oraz naprzemienność umieszczenia kandydatów i kandydatek na listach wyborczych. Wnioskodawcy

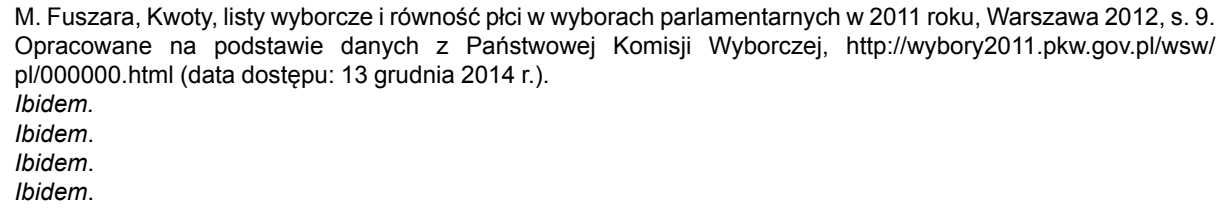

M. Fuszara, Kwoty, listy wyborcze i równość płci w wyborach parlamentarnych w 2011 roku, Warszawa 2012, s. 9. Opracowane na podstawie danych z Państwowej Komisji Wyborczej, http://wybory2011.pkw.gov.pl/wsw/ $\mathrm{pl} / 000000 . \mathrm{html}$ (data dostępu: 13 grudnia 2014 r.). Ibidem. Ibidem. Ibidem. Ibidem. 
uzasadnili, że tylko takie rozwiązanie zagwarantuje równość polityczną kobiet i mężczyzn w życiu politycznym. ${ }^{27}$ Wątpliwości budzi konstytucyjność zapisu o parytetach. W opinii wydanej przez Andrzeja Seremeta zostało wskazane, że rozwiązanie parytetowe jest niezgodne z Konstytucją, ponieważ płeć nie jest obiektywnym kryterium oceny i może doprowadzić do nieuzasadnionej nierówności. ${ }^{28} \mathrm{~W}$ styczniu 2013 roku do marszałek Ewy Kopacz trafił przygotowany przez Parlamentarną Grupę Kobiet następny projekt ustawy - o zmianie ustawy - kodeksu wyborczego ${ }^{29}$ z lipca 2011 roku. Projekt ten zakład wprowadzenie naprzemiennego umieszczania kobiet i mężczyzn na listach wyborczych do Sejmu, rady gmin, miast, powiatów, sejmików wojewódzkich, a także do Parlamentu Europejskiego. Wnioskodawczynie podnoszą argument, że praktyki w konstruowaniu przez partie list wyborczych wyraźnie faworyzując mężczyzn. „Sprawiedliwa byłaby zasada, zgodnie z którą 3 kobiety i mężczyźni stanowiliby taki sam odsetek osób umieszczonych na pierwszym miejscu list. ${ }^{30} \mathrm{~W}$ obu uzasadnieniach uznano, że same rozwiązanie kwotowe nie jest dostatecznie skutecznym mechanizmem, co pokazały wybory parlamentarne w 2011 roku. Wskazano, że praktyka stosowania obecnie obowiązujących przepisów prawa nie zapewnia w pełni równości pomiędzy kobietami i mężczyznami w zakresie sposobu umieszczania ich na listach wyborczych. Pojawiły się również głosy, że rozwiązanie suwakowe nie przyniesie żadnych zmian, a może jeszcze pogorszyć obecną sytuację. Dr Jarosław Flis w opinii sejmowej do projektów ustaw wprowadzających parytet na listach wyborczych argumentuje, że ustawa najprawdopodobniej nie doprowadzi do żadnego z zamierzonych efektów końcowych. ${ }^{31}$ Wywarcie nacisku na partie polityczne, aby umieszczały kobiety na wyższych pozycjach na listach wyborczych, może okazać się nieskuteczne, ponieważ w polskim systemie wyborczym $90 \%$ miejsc jest niedającymi szans na wybór. ${ }^{32}$ Wynika to z modelu otwartych list wyborczych i przeświadczenia partii, że tylko z miejsca pierwszego kandydat jest wstanie wygrać wybory, dlatego też najbardziej rozpoznawani politycy są umieszczani na najwyższych miejscach list wyborczych.$^{33}$ Chociaż w maju 2014 roku projekt ustawy zgłoszony przez Parlamentarną Grupę Kobiet został przyjęty przez nadzwyczajną komisję, to wciąż trwają pracę parlamentarne nad zaproponowanymi rozwiązaniami. 


\section{Podsumowanie}

Wprowadzanie mechanizmu zapewniającego większą partycypację kobiet w polskim parlamencie było długotrwałym procesem, który rozpoczął się w latach 90 XX w., a zakończył dopiero w 2011 roku. Uchwalona ustawa kwotowa jest kompromisem pomiędzy projektem ustawy zaproponowanej w ramach obywatelskiej inicjatywy ustawodawczej a tym, na co zgodził się polski ustawodawca. Krótko po uchwaleniu zmiany o ordynacji wyborczej była możliwość sprawdzenia efektywności przyjętego mechanizmu. Po wyborach parlamentarnych w 2011 roku, liczba kobiet w Sejmie w zrosła o 3,9 pkt. procentowych w porównaniu do kadencji Sejmu w 2007 roku. Przyczynę tego niewielkiego wzrostu można upatrywać w wewnętrznej polityce partii stosowanej podczas rozdzielenia miejsc na listach wyborczych. Pomimo tego że partie zastosowały się do wymogu $35 \%$ z nadwyżką, to kobiety nie zawsze startowały z korzystnych miejsc na listach wyborczych. Praktyka polskich wyborów pokazuje, że im wyższe miejsce kandydat zajmuje na liście, tym większe prawdopodobieństwo zwycięstwa. W związku z tym Parlamentarna Grupa Kobiet oraz Ruch Palikota przygotowali nowelizację ordynacji wyborczej, proponując wprowadzenie suwaków na listach wyborczych. Podnoszą argument, że mechanizm kwot suwakowych jest skuteczniejszym rozwiązaniem ze względu na przymus naprzemiennego umieszczania kandydatów kobiet i kandydatów mężczyzn na listach wyborczych. Praktyka suwakowa, zastosowana przez PO podczas konstruowania list w wyborach w 2011 roku okazała się korzystniejsza dla kandydatek kobiet i umożliwiła im wejście do Sejmu. Pojawiają się również opinie, że wprowadzenie kwoty suwakowej może wcale nie przyczynić się do zwiększenia partycypacji kobiet w polityce. Ponieważ wciąż trwają pracę nad polskim projektem ustawy suwakowej i nie ma jednoznacznej opinii co do skuteczności nowelizacji, dopiero w praktyce będzie można przekonać się o jej efektywności. Skutkiem obecnie obowiązującego rozwiązania prawnego jest wzrost liczby kobiet - kandydatów na listach wyborczych. Ułatwiony dostęp do list wyborczych może w dalszej perspektywie pomóc kobietom zaistnieć na scenie politycznej, a tym samym zwiększyć ich szanse na zwycięstwo w kolejnych wyborach.

\section{BIBLIOGRAFIA}

Balińska B., Polityka równości płci. Polska 2007 Raport, Warszawa 2007

Czaplicki K.W., Dauter B., Jaworski S. J., Kisielewicz A., Rymarz F., Kodeks wyborczy. Komentarz, Wolters Kluwer, Warszawa 2014

Dunaj B., Wielki słownik języka polskiego, Warszawa 2009

Fuszara M., Kwoty, listy wyborcze i równość płci w wyborach parlamentarnych w 2011 roku, Instytutu Spraw Publicznych, Warszawa 2012

Fuszera M., Kobiety, wybory, polityka, Instytut Spraw Publicznych, Warszawa 2013 
Rakowska A., Skotnick K., Zmiany w prawie wyborczym wprowadzone przez kodeks wyborczy, „Przegląd Sejmowy” 2011, nr 4(105)

Raciborski, F., Raciborski J., Kobiety w roli paprotek. Internetowe wydanie „Rzeczpospolitej”,28.08.2009 na: http://www.rp.pl/artykul/9133,355026.html (data dostępu: 13.11.2014)

Skotnicki K., Szmyta A., Wieruszowski R., Sękowska-Kozłowska K., Opinie w sprawie wprowadzenia parytetu płci na listach wyborczych, „Przegląd sejmowy” 2010, nr 3(98)

Siemieńska R., Płeć, wybory, władza, Friedrich Ebert Stiftung 2005, Warszawa 2005

Szewczyk M., Parytet płci w ujęciu prawno porównawczym, Studia Iuridica Toruniensia, tom 9/211, Wydawnictwo Naukowe Uniwersytetu Mikołaja Kopernika w Toruniu, Torun 2011

Wawrowski Ł., Polityka równych szans. Instytucjonalne mechanizmy zwiększania partycypacji kobiet w strukturach politycznych na przykładzie państw Unii Europejskiej, Wydawnictwo Adam Marszałek, Toruń 2007

Wawrowski Ł., Co da Polkom tzw. ustawa parytetowa? Studia BAS Nr 2(26) 2011, Warszawa 2011

Żukowski A., Partycypacja wyborcza kobiet - wyzwania i dylematy, Centrum Studiów Wyborczych, Toruń 2011 


\section{THE MECHANISM OF QUOTA IN THE LIGHT OF ELECTORAL CODE REGULATIONS INTRODUCED IN 2011}

The article describes the process of introducing the electoral quota system into Polish legislation. This system is one of the most popular instruments for increasing the participation of women in politics. Women are underrepresented in the Polish Parliament with only $23,9 \%$ of politicians being female. This situation was supposed to be changed by implementing the electoral quota system, which requires the equal number of $35 \%$ male and female candidates in the electoral polls for all parliamentary, district council and county council elections. The first draft of the electoral quota act was the Parity Act, proposed as one of the people's legislative initiatives in 2009. The article also describes the attempts to increase the required number of 35\% male and female candidates by implementing the clause which sets the rule of placing the names of female and male candidates alternately on the electoral polls, the so-called "zip quota".

Keywords: Women in politics, electoral quota, parity system, electoral list, act of 2011

Słowa kluczowe: Kobiety w polityce, kwoty wyborcze, parytety wyborcze, listy wyborcze, kodeks wyborczy z 2011 roku 